\title{
MEKANISME PENEGAKAN HUKUM PERKARA PIDANA PORNOGRAFI MELALUI INTERNET
}

\author{
Hwian Christianto \\ Email: hwall4jc@yahoo.co.id
}

\begin{abstract}
Internet child pornography is criminalized in three different regulations, i.e. the Criminal Procedural Act (no. 8/1981), Electronic/Digital Information and Transaction Act (Act no. 11/2008) and Pornography Act (Act no. 44/2008). As a result, law enforcers has to choose between these three different rulings and this may create uncertainty in which ruling from which act should prevail. The author compares the above acts and reveals the comparative advantage of these three different acts in dealing with child pornography. The main finding here is that each act should be considered supplementary to each other and in combination should be enforced in such a way as to yield justice and legal certainty.
\end{abstract}

Keywords:

formal criminal law, criminal case, pornography, internet

\begin{abstract}
Abstrak
Pengaturan hukum pidana formil dari pidana pornografi melalui internet tidak semata mendasarkan diri pada KUHAP (UU No. 8 Tahun 1981) melainkan juga Undang-Undang Informasi dan Transaksi Elektronik (UU No. 11 Tahun 2008) serta Undang-Undang Pornografi (UU No. 44 Tahun 2008). Adanya tiga peraturan perundang-undangan berbeda memunculkan persoalan ketentuan manakah yang harus diberlakukan ketika berhadapan dengan kasus-kasus pornografi melalui internet. Kajian secara mendalam terhadap ketiga peraturan perundang-undangan menunjukkan bahwa masing-masing memiliki keunggulannya sendiri. Temuan terpenting di sini adalah bahwa seharusnya ketiganya dapat saling melengkapi dan dikombinasikan untuk menghadirkan kepastian hukum dan keadilan ketika berhadapan dengan kasus-kasus pornografi anak.
\end{abstract}

Kata kunci:

hukum pidana formil, perkara pidana, pornografi, internet

\section{Pendahuluan}

Hukum pidana formil menjadi bagian penting dari pemberlakuan hukum di masyarakat. Pemahaman hukum pidana formil selalu berfokus pada hukum acara pidana $^{1}$ yang mengatur tentang tata cara atau prosedur yang harus dipenuhi untuk menegakkan ketentuan hukum pidana yang dilanggar melalui badan-badan Negara (polisi, jaksa dan hakim). ${ }^{2}$ Keberadaan hukum pidana formil ini sangat penting terutama dalam perkara pornografi melalui internet karena perbuatan pornografi melalui internet pada dasarnya merupakan pelanggaran terhadap

1 Andi Hamzah, Asas-Asas Hukum Pidana, Rineka Cipta, Jakarta, 2010, hlm., 1.

2 E.Y. Kanter \& S.R. Sianturi, Asas-asas Hukum Pidana di Indonesia dan Penerapannya, Storia Grafika, Jakarta, 2012, hlm., 20. 
hukum pidana materil yang berlaku (Kitab Undang-Undang Hukum Pidana, Undang-Undang Nomor 11 Tahun 2008 atau Undang-Undang Nomor 44 Tahun 2008). Partodihardjo menegaskan bahwa pelanggaran konten laman internet terbanyak saat ini terkait dengan pornografi dalam bentuk gambar, cerita maupun gambar bergerak. ${ }^{3}$ Data Kementerian Komunikasi dan Informatika pada akhir tahun 2015 telah berhasil memblokir 766.394 laman internet yang dinilai memiliki konten negatif. ${ }^{4}$ Laman yang mengandung konten pornografi sendiri menempati peringkat teratas sebagai alasan pemblokiran laman internet dengan prosentase $98,32 \%$ (735.497 laman). ${ }^{5}$

Berbagai kasus pornografi melalui internet dalam berbagai macam bentuk telah terjadi di masyarakat sebagai bentuk penyalahgunaan media internet. Penegakan hukum atas pelanggaran hukum tersebut secara umum memiliki kesamaan dengan penegakan hukum atas pelanggaran hukum pada perkara pidana lainnya. Perbedaan yang unik justru muncul sebagai akibat adanya keunikan karakteristik dari perbuatan pornografi yang menggunakan media internet. Pengaturan terhadap hukum pidana formil terhadap perkara pornografi sejauh ini telah mendapatkan pengaturan secara khusus dalam Undang-Undang No. 11 Tahun 2008 tentang Informasi dan Transaksi Elektronik (UU ITE) maupun Undang-Undang Nomor 44 Tahun 2008 tentang Pornografi (UU Pornografi).

UU ITE memberikan pengaturan tersendiri dalam hal penanganan perkara pornografi internet baik terkait prosedur penegakan hukum maupun alat bukti yang baru dalam hukum acara pidana. Di sisi lain pengaturan UU Pornografi juga memberikan penekanan khusus dalam menanggulangi perbuatan pornografi. Hal tersebut tampak dalam pengaturan mekanisme penanganan perkara pornografi yang lebih khusus jika dibandingkan dengan penanganan perkara pidana pada umumnya. Kedua pengaturan hukum acara pidana yang berlaku dalam

\footnotetext{
3 Soemarno Partodihardjo, Tanya Jawab Sekitar Undang-Undang Nomor 11 Tahun 2008 tentang Informasi dan Transaksi Elektronik, Gramedia Pustaka Utama, Jakarta, 2009, hlm., 46.

4 Siaran Pers No. 101/PIH/KOMINF0/12/2015, "Siaran Pers tentang Pemblokiran Situs Judi dan Pornografi”, http://kominfo.go.id/index.php/content/detail/6555/Siaran-Pers-NO-101-PIHKOMINFO-12-2015-Tentang-Pemblokiran-Situs-Judi-dan-Pornografi /0/siaran_pers\#.Vqb6QVJjLIU, 31 Desember 2015, dunduh 22 Januari 2016 5 Id.
} 
penanganan perkara pidana pornogafi melalui internet menjadi sebuah hal yang menarik untuk dibahas lebih lanjut. Kejelasan atas prosedur mana yang berlaku menjadi bagian penting dalam hukum acara pidana sebagai sarana penegakan hukum tanpa harus merampas hak asasi manusia sebagai akibat ketidakpastian hukum.

\section{Pembahasan}

Mekanisme Khusus Penegakan Hukum Pidana menurut Undang-Undang No. 11 Tahun 2008 tentang Informasi dan Transaksi Elektronik terhadap Perkara Pidana Pornografi melalui Internet

Sejak diundangkannya UU ITE pada 21 April 2008, Indonesia telah memiliki hukum khusus yang mengatur tentang segala perbuatan yang dilakukan menggunakan internet. Pengaturan dalam bidang hukum pidana telah dilakukan baik dari segi hukum pidana materiil yang terdapat dalam Bab VII, pasal 27- pasal 37 UU ITE maupun segi hukum pidana formiil yang terdapat dalam Bab X, pasal 42- pasal 44 UU ITE. Pengaturan hukum pidana formil secara khusus dalam UU ITE menunjukkan adanya pemahaman akan perbedaan penanganan terhadap perkara pidana informasi dan transaksi elektronik, termasuk di dalamnya perbuatan pidana pornografi melalui internet. Hanya saja pengaturan dalam UU ITE terkait hukum pidana formil tidak menjabarkan secara rinci prosedur apa saja yang harus dilakukan pada saat penegak hukum menghadapi perkara pidana informasi dan transaksi elektronik. Penegakan hukum saat terjadi perkara pidana seharusnya dapat dilakukan dalam sebuah rangkaian proses hukum mulai dari penyidikan, penuntutan, pemeriksaan sidang pengadilan, putusan, dan upaya hukum. Oleh karena itu pembahasan secara mendalam akan dilakukan terhadap tiap tahap mekanisme penegakan hukum yang diatur dalam UU ITE.

Mengenai pengaturan tentang penyidikan perkara pidana informasi Pasal 42 UU ITE memberikan penegasan bahwa tata cara penyidikan yang berlaku dalam UU ITE adalah penyidikan sebagaimana diatur dalam Undang-Undang Hukum Acara Pidana (Undang-Undang Nomor 8 Tahun 1981, selanjutnya disebut KUHAP) ditambah dengan ketentuan lain yang diatur secara khusus dalam UU ITE. 
Pengaturan ini pada dasarnya menunjukkan bahwa KUHAP masih menjadi dasar penanganan perkara pidana informasi dan transaksi elektronik sepanjang tidak merumuskan adanya pengaturan khusus. Berdasarkan hal tersebut maka penyidikan tetap didasarkan pada Pasal 1 angka 2 KUHAP yang memberikan pengaturan bahwa:

"Penyidikan adalah serangkaian tindakan penyidik dalam hal dan menurut cara yang diatur dalam Undang-Undang ini untuk mencari serta mengumpulkan bukti yang dengan bukti itu membuat terang tentang tindak pidana yang terjadi dan guna menemukan tersangkanya."

Berdasarkan pengertian pasal 1 angka 2 KUHAP, penyidikan sudah menunjukkan tahapan berbeda jika dibandingkan dengan penyelidikan. Penyidikan berfokus pada pengumpulan bukti untuk dapat menunjukkan bentuk perbuatan pidana yang terjadi dan menemukan pelaku dari perbuatan pidana tersebut. Berbeda halnya dengan penyelidikan yang bertujuan untuk mengetahui ada atau tidaknya perbuatan pidana. Penegak hukum yang bertugas dalam tahap penyidikan ini terdiri dari pejabat polisi Republik Indonesia atau pejabat pegawai negeri sipil tertentu yang diberi wewenang khusus oleh Undang-Undang untuk melakukan penyidikan. Terkait dengan penyidik dalam perkara pidana informasi dan transaksi elektronik ini Pasal 43 angka 1 UU ITE memberikan penegasan bahwa pejabat pegawai negeri sipil tertentu yang dimaksudkan adalah Pejabat Pegawai Negeri Sipil (PPNS) tertentu di lingkungan Pemerintah yang lingkup tugas dan tanggung jawabnya di bidang Teknologi Informasi dan Transaksi Elektronik yang diberi wewenang melakukan penyidikan. PPNS Pemerintah di bidang Teknologi Informasi dan Transaksi Elektronik yang berwenang melakukan penyidikan dalam hal perbuatan pidana informasi dan transaksi elektronik berada pada kewenangan Kementerian Komunikasi dan Informatika dengan Unit Kerja Inspektorat Jenderal Kementerian Komunikasi dan Informatika. Adapun tugas penyidikan dalam perkara pidana informasi dan transaksi elektronik didasarkan atas perlindungan terhadap privasi, kerahasiaan, kelancaran pelayanan publik dan integritas data atau keutuhan data (pasal 43 angka 2 UU ITE). Wewenang penyidik 
sebagaimana diatur dalam pasal 43 angka 3-8 UU ITE tergambar dalam tabel berikut:

Tabel 1. Wewenang Khusus dari Penyidik dalam Perkara Pidana ITE

\begin{tabular}{|c|c|c|c|}
\hline No. & Wewenang & Tata Cara & Ketentuan Hukum \\
\hline 1. & $\begin{array}{ll}\text { Penggeledahan } & \text { terhadap } \\
\text { Sistem elektronik } & \\
\end{array}$ & $\begin{array}{l}\text { Izin ketua Pengadilan Negeri } \\
\text { setempat }\end{array}$ & Pasal 43 angka 2 dan 3 \\
\hline 2. & $\begin{array}{lll}\text { Penyitaan } & \text { terhadap } & \text { Sistem } \\
\text { elektronik } & & \\
\end{array}$ & $\begin{array}{l}\text { Izin ketua Pengadilan Negeri } \\
\text { setempat }\end{array}$ & Pasal 43 angka 2 dan 3 \\
\hline 3. & $\begin{array}{l}\text { Menerima laporan atau } \\
\text { pengaduan dari seseorang }\end{array}$ & KUHAP & Pasal 43 angka 5 huruf a \\
\hline 4. & $\begin{array}{l}\text { Memanggil setiap orang atau } \\
\text { pihak lain untuk didengar atau } \\
\text { diperiksa sebagai tersangka } \\
\text { atau saksi }\end{array}$ & KUHAP & Pasal 43 angka 5 huruf b \\
\hline 5. & $\begin{array}{lc}\text { Melakukan pemeriksaan } & \text { atas } \\
\text { kebenaran laporan } & \text { dan } \\
\text { pengaduan seseorang } & \\
\end{array}$ & KUHAP & Pasal 43 angka 5 huruf c \\
\hline 6. & $\begin{array}{l}\text { Melakukan pemeriksaan } \\
\text { terhadap orang dan/atau } \\
\text { badan usaha }\end{array}$ & KUHAP & Pasal 43 angka 5 huruf d \\
\hline 7. & $\begin{array}{l}\text { Melakukan pemeriksaan } \\
\text { terhadap alat dan/atau sarana } \\
\text { yang berkaitan dengan } \\
\text { kegiatan Teknologi Informasi } \\
\text { yang diduga digunakan untuk } \\
\text { melakukan perbuatan pidana } \\
\text { ITE }\end{array}$ & UU ITE & Pasal 43 angka 5 huruf e \\
\hline 8. & $\begin{array}{l}\text { Melakukan penggeledahan } \\
\text { terhadap tempat tertentu yang } \\
\text { diduga sebagai tempat } \\
\text { melakukan perbuatan pidana } \\
\text { ITE }\end{array}$ & UU ITE & Pasal 43 angka 5 huruf f \\
\hline 9. & $\begin{array}{l}\text { Melakukan penyegelan dan } \\
\text { penyitaan terhadap alat dan } \\
\text { atau sarana kegiatan } \\
\text { Teknologi Informasi yang } \\
\text { diduga digunakan secara } \\
\text { menyimpang dari ketentuan } \\
\text { peraturan perundang- } \\
\text { undangan }\end{array}$ & UU ITE & Pasal 43 angka 5 huruf g \\
\hline 10. & $\begin{array}{l}\text { Meminta bantuan ahli untuk } \\
\text { membantu penyidikan }\end{array}$ & UU ITE & Pasal 43 angka 5 huruf h \\
\hline 11. & $\begin{array}{l}\text { Menghentikan penyidikan } \\
\text { perbuatan pidana ITE }\end{array}$ & UU ITE & Pasal 43 angka 5 huruf i \\
\hline 12. & $\begin{array}{l}\text { Melakukan penangkapan atas } \\
\text { tersangka perbuatan pidana } \\
\text { ITE }\end{array}$ & $\begin{array}{l}\text { Meminta penetapan } \\
\text { Pengadilan Negeri setempat } \\
\text { dalam waktu } 1 \text { x } 24 \text { jam } \\
\text { melalui Penuntut umum }\end{array}$ & Pasal 43 angka 6 \\
\hline 13. & $\begin{array}{l}\text { Melakukan penahanan atas } \\
\text { tersangka perbuatan pidana }\end{array}$ & $\begin{array}{l}\text { Meminta penetapan } \\
\text { Pengadilan Negeri setempat }\end{array}$ & Pasal 43 angka 6 \\
\hline
\end{tabular}




\begin{tabular}{llll}
\hline & ITE & $\begin{array}{l}\text { dalam waktu 1 x 24 jam } \\
\text { melalui Penuntut umum }\end{array}$ & \\
\hline 14. & $\begin{array}{l}\text { Dapat Bekerjasama dengan } \\
\text { penyidik Negara lain untuk } \\
\text { berbagi informasi dan alat } \\
\text { bukti untuk mengungkap } \\
\text { perbuatan pidana ITE }\end{array}$ & \\
\hline
\end{tabular}

Ketigabelas wewenang penyidikan tersebut saat dilakukan oleh PPNS Kementerian Komunikasi dan Informatika pada dasarnya tidak berlaku secara mutlak. Hal tersebut didasarkan pada pengaturan pasal 43 angka 7 UU ITE yang menegaskan pelaksanaan penyidikan oleh PPNS Kementerian Komunikasi dan Informatika dikoordinasikan oleh Penyidik Pejabat Polisi Negara Republik Indonesia. Dengan demikian maka wewenang penyidik PPNS Kementerian Komunikasi dan Informatika pada dasarnya bersifat koordinatif dengan pihak kepolisian.

Sejauh ini upaya penyidikan dari PPNS Kementerian Komunikasi dan Informatika terkait dengan perbuatan pornografi melalui internet tampak dalam langkah pemblokiran laman internet yang mengandung konten negatif. Maksud dari laman internet yang mengandung konten negatif diantaranya Pornografi, SARA, Penipuan/Dagang illegal, Narkoba, Perjudian, Radikalisme, Kekerasan/Violence, Kekerasan/Pornografi Anak, Keamanan Internet, Pelanggaran Hak Kekayaan Intelektual, konten lain-lain dan normalisasi. Mekanisme yang diterapkan dalam melakukan pemblokiran diperoleh dari aduan masyarakat yang dilakukan secara umum melalui alamat email aduankonten@kominfo.go.id atau dengan mengakses situs http://trustpositif.kominfo.go.id. Kementerian Komunikasi dan Informatika setelah mendapatkan laporan atau pengaduan, langsung melakukan pemeriksaan terhadap kebenaran laporan dengan membentuk Rapat Panel Ahli yang terdiri atas 4 (empat) panel yaitu Panel Pertama, Bidang Pornografi dan Kekerasan terhadap Anak dan Keamanan Internet, Panel Kedua Bidang Teroris dan SARA, Panel Ketiga Bidang Investigasi Ilegal, Penipuan, Perjudian, Obat dan Makanan 
serta Narkoba dan Panel Keempat Bidang Hak Kekayaan Intelektual. ${ }^{6}$ Hal yang menarik dari tindak lanjut pemeriksaan laman yang dinilai memiliki konten negatif justru dengan melakukan pemblokiran atas laman tersebut. UU ITE tidak menyebutkan secara eksplisit upaya pemblokiran sebagai wewenang dari penyidik. Ketentuan Hukum pasal 43 angka 5 huruf g UU ITE hanya mengenal upaya penyegelan yang identik dengan upaya pemblokiran. Pengertian istilah "Penyegelan" adalah proses atau cara membubuhkan meterai atau cap"7 sedangkan istilah "pemblokiran" berarti "memberhentikan"8. Simanjuntak menegaskan bahwa penyegelan merupakan tindakan pengamanan dengan melakukan penutupan tempat sebagai bagian dari upaya paksa keras untuk pelaksanaan hukum acara. ${ }^{9}$ Dilihat dari kedua pengertian tersebut dapat diperoleh pemahaman bahwa kedua upaya tersebut tidak memiliki ciri yang sama dalam hal membuat obyek menjadi tidak dapat digunakan sebagaimana mestinya. Oleh karena itu upaya penyegelan tidak dapat dianggap sebagai bagian dari proses penyidikan yang dilakukan oleh Kementerian Komunikasi dan Informatika. Sejalan dengan pemikiran ini, Dewi Bunga ${ }^{10}$ juga menegaskan upaya pemblokiran laman internet yang mengandung konten prostitusi (pornografi) merupakan bagian dari upaya penegakan hukum dalam langkah pencegahan.

Tahap penuntutan terhadap perkara pidana pornografi melalui internet menurut UU ITE merupakan wewenang khusus dari jaksa penuntut umum. Ketentuan hukum pasal 43 angka 7 UU ITE menegaskan bahwa apapun hasil penyidikan selanjutnya harus diserahkan kepada Penuntut Umum. Terkait dengan perbuatan pidana pornografi melalui internet, pada umumnya jaksa penuntut umum menggunakan ketentuan hukum pasal 27 ayat (1) UU ITE. Penggunaan ketentuan hukum tersebut didasarkan pada pertimbangan adanya sarana internet

${ }^{6}$ Id.

7 Penyusun Kamus Pusat Pembinaan dan Pengembangan Bahasa, Kamus Besar Bahasa Indonesia, Jakarta, 1991, hlm., 890.

8 Id. hlm., 139

9 Nikolas Simanjuntak, Acara Pidana Indonesia dalam Sirkus Hukum, Ghalia Indonesia, Bogor, 2009 hlm., 108.

${ }^{10}$ Dewi Bunga, Prostitusi Cyber: Diskursus Penegakan Hukum dalam Anatomi Kejahatan Transnasional, Udayana University Press, Bali, 2012, hlm., 64. 
yang digunakan untuk menampilkan atau menyebarluaskan informasi elektronik yang berkonten pornografi. Dengan kata lain, perbuatan pornografi melalui internet dipandang sebagai penggunaan internet yang menyimpang dari tujuan yang ditetapkan. Penuntut Umum pun dapat membuat Surat Dakwaan dengan berbagai macam bentuk tergantung pada posisi kasus yang ada. Untuk perbuatan yang jelas melakukan pelanggaran terhadap pasal 27 ayat (1) UU ITE dapat digunakan bentuk dakwaan tunggal, sebagaimana surat dakwaan yang dibuat oleh Jaksa Penuntut Umum pada Perkara Penyebaran Foto Bugil melalui akun Facebook dengan terdakwa AK pada Putusan Nomor 124/Pid/SUS/2013/PN.Srg tertanggal 29 Agustus 2013. ${ }^{11}$ Selain itu penggunaan bentuk dakwaan alternatif dilakukan oleh Jaksa Penuntut Umum manakala menangani pornografi melalui internet yang dapat ditunjukkan di muka umum atau dilakukan sebagai mata pencaharian. Kasus Perbuatan mengirimkan SMS (short messages services) yang berisikan percakapan aktivitas seksual pada berkas Putusan Nomor 393/Pi.B/2014/PN.Pdg tertanggal 10 September 2014 dituntut dengan Dakwaan Kesatu, Pasal 27 ayat (1) jo. Pasal 36 jo. Pasal 45 UU ITE Dakwaan Kedua, pasal 282 ayat (1), ayat (3) KUHP. ${ }^{12}$ Kedua bentuk surat dakwaan tersebut sekali lagi sangat bergantung pada perkara pornografi melalui internet yang ditangani oleh jaksa penuntut umum, tentu saja dengan tetap mendasarkan diri pada posisi kasus dan alat bukti yang ada.

Tahap pemeriksaan di sidang Pengadilan, merupakan bagian dari pelaksanaan hukum pembuktian yang berlaku dalam KUHAP. UU ITE sendiri tidak memberikan pengaturan secara khusus tentang pemeriksaan perkara pidana informasi dan transaksi elektronik oleh karenanya sebagai konsekuensi dari pelaksanaan pasal 41 UU ITE berlakulah model pembuktian yang diatur dalam KUHAP. Tujuan dari pemeriksaan di sidang pengadilan tidak lain untuk mengumpulkan fakta hukum yang diperoleh berdasarkan alat bukti yang sah di depan persidangan.

${ }^{11} \mathrm{http}$ ://putusan.mahkamahagung.go.id/, putusan diunduh 22 Januari 2016 12 Id. 
Tahap Putusan pengadilan merupakan bagian akhir dari proses pemeriksaan sidang yang berisikan fakta hukum dan barang bukti sebagai dasar bagi hakim untuk memberikan putusan. Secara yuridis normatif, UU ITE tidak memberikan pengaturan secara khusus terhadap pertimbangan hakim maupun putusan sehingga berlakulah hukum acara pidana dalam KUHAP.

\section{Mekanisme Khusus dalam Hukum Pidana Formil menurut Undang-Undang No. 44 Tahun 2008 tentang Pornografi}

Tidak seperti ketentuan hukum lain, hadirnya UU Pornografi mendapatkan rekasi pro dan kontra dari berbagai pihak dengan alasan pengekangan kebebasan berekspresi, isu gender sampai pada perlindungan kepentingan masyarakat. Konsideran UU Pornografi sendiri menyebutkan bahwa adanya pornografi dalam berbagai macam bentuk perkembangannya mengancam kehidupan dan tatanan sosial masyarakat Indonesia. Pertimbangan tersebut menegaskan akan pentingnya perlindungan terhadap kepentingan umum melalui peran hukum pidana. UU Pornografi yang berlaku sejak 26 November 2008 juga memiliki pengaturan unik karena tidak hanya mengatur perihal hukum pidana materil melainkan hukum pidana formil. Perbuatan pornografi beserta dengan sanksi pidana atas pelanggaran ketentuan hukum yang berlaku, diatur dalam BAB II mulai dari Pasal 4 - pasal 14 UU Pornografi. Sedangkan ancaman pidanamya terdapat pada pasal 29 - pasal 41 UU Pornografi. Berbeda halnya dengan UU ITE yang hanya memberikan pengaturan hukum pidana formil pada tahap penyidikan, secara khusus UU Pornografi mengatur pidana formil dalam BAB V mulai dari tahap Penyidikan, Penuntutan dan Pemeriksaan di Sidang Pengadilan. Pengaturan tersebut menunjukkan adanya perhatian khusus dari pembuat undang-undang terhadap penanganan pornografi jika dibandingkan dengan perkara lainnya.

Secara normatif, memang BAB V UU Pornografi memberikan pengaturan terhadap hukum acara pidana yang berlaku dalam menangani perkara pidana pornografi. Hanya saja berdasarkan ketentuan Pasal 23 UU Pornografi ditegaskan bahwa "penyidikan, penuntutan, dan pemeriksaan di sidang pengadilan terhadap pelanggaran pornografi dilaksanakan berdasarkan Undang-Undang tentang 
Hukum Acara Pidana, kecuali ditentukan lain dalam Undang-Undang ini." Pengaturan tersebut menunjukkan bahwa pengaturan hukum acara pidana yang berlaku pada perkara pidana pornografi masih didasarkan pada KUHAP. Kekhususan pengaturan yang terdapat dalam UU Pornografi dapat ditinjau dalam subtansi mekanisme yang diatur mulai dari Pasal 24 sampai dengan pasal 27 UU Pornografi. Berikut ini disajikan secara ringkas, pengaturan khusus dalam UU Pornografi yang mempengaruhi hukum acara pidana yang berlaku dalam menangani perkara pidana pornografi.

Tabel 2.Pengaturan Khusus Hukum Acara Pidana menurut UU Pornografi

\begin{tabular}{|c|c|c|c|}
\hline No. & Hal yang Diatur & Tata Cara & Ketentuan Hukum \\
\hline 1. & $\begin{array}{l}\text { Wewenang Penyidik untuk } \\
\text { membuka akses, memeriksa, } \\
\text { dan membuat salinan data } \\
\text { elektronik yang tersimpan } \\
\text { dalam fail komputer, jaringan } \\
\text { internet, media optik, serta } \\
\text { bentuk penyimpanan data } \\
\text { elektronik lainnya }\end{array}$ & $\begin{array}{l}\text { Tidak diatur dengan jelas } \\
\text { terkait mekanisme membuka } \\
\text { akses, memeriksa dan } \\
\text { membuat salinan data } \\
\text { elektronik }\end{array}$ & Pasal 25 ayat (1) \\
\hline 2. & $\begin{array}{l}\text { Kewajiban pemilik data, } \\
\text { penyimpan data, atau } \\
\text { penyedia jasa layanan } \\
\text { elektronik untuk } \\
\text { menyerahkan dan/atau } \\
\text { membuka data elektronik } \\
\text { yang diminta penyidik }\end{array}$ & $\begin{array}{l}\text { Tidak diatur dengan jelas } \\
\text { mekanisme pemberitahuan } \\
\text { atau hal yang harus } \\
\text { ditunjukkan penyidik } \\
\text { sebelum pemilik data } \\
\text { melakukan penyerahan datau } \\
\text { membuka data elektronik } \\
\text { yang diminta }\end{array}$ & Pasal 25 ayat (2) \\
\hline 3. & $\begin{array}{l}\text { Hak dari pemilik data, } \\
\text { penyimpan data, atau } \\
\text { penyedia jasa layanan } \\
\text { elektronik untuk } \\
\text { mendapatkan tanda terima } \\
\text { penyerahan atau berita acara } \\
\text { pembukaan data elektronik } \\
\text { dari penyidik }\end{array}$ & Sudah jelas & $\begin{array}{l}\text { Pasal } 25 \text { ayat }(3) \& \\
\text { Pasal } 26\end{array}$ \\
\hline 4. & $\begin{array}{l}\text { Pengakuan data dalam bentuk } \\
\text { tulisan atau gambar dalam } \\
\text { bentuk cetakan, elektronik, } \\
\text { optic atau bentuk } \\
\text { penyimpanan sebagai alat } \\
\text { bukti }\end{array}$ & Sudah jelas & Pasal 24 huruf a \\
\hline 5. & $\begin{array}{l}\text { Pengakuan data elektronik } \\
\text { sebagai alat bukti }\end{array}$ & Sudah jelas & Pasal 24 huruf b \\
\hline 6. & $\begin{array}{l}\text { Perlakuan khusus pada data } \\
\text { elektronik: } \\
\text { a. Pelampiran data } \\
\text { elektronik yang diperiksa }\end{array}$ & $\begin{array}{l}\text { Tidak ada pengaturan lebih } \\
\text { lanjut terkait cara pelampiran }\end{array}$ & Pasal 27 ayat (1) \\
\hline
\end{tabular}




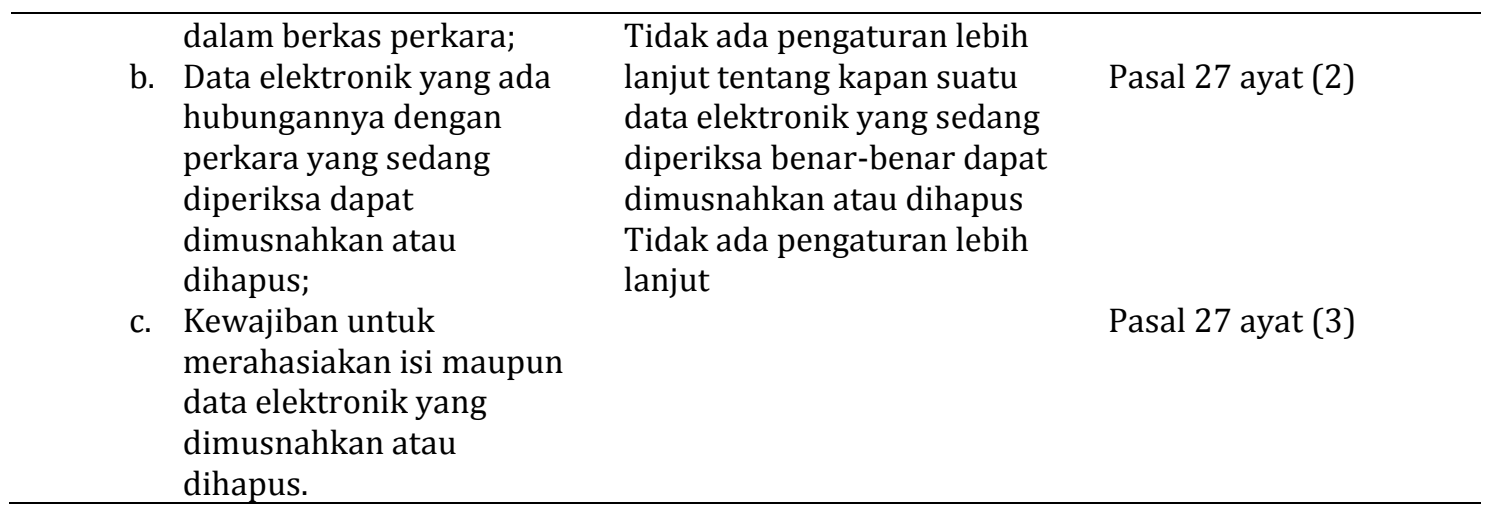

Berdasarkan pengaturan khusus tersebut, UU Pornografi tampak dengan jelas memberikan penekanan pada perkembangan media informasi maupun telekomunikasi sebagai sarana penyebaran pornografi. Sebenarnya pengaturan mengenai larangan penyebaran pornografi sudah terdapat pada tiap undangundang yang mengatur tentang pertukaran informasi. Pasal 18 ayat (2) jo. Pasal 5 ayat (1) UU Pers, Pasal 57 jo Pasal 42 ayat (1) UU Telekomunikasi dan Pasal 57 huruf d jo. Pasal 36 ayat (5) huruf b UU Penyiaran. Keberadaan pengaturan khusus dalam pasal 24 sampai dengan pasal 27 UU Pornografi memberikan sebuah solusi untuk menangani perkara pidana pornografi dengan lebih cepat dan mudah.

Tahap penyidikan dalam perkara pidana pornografi ternyata tidak memberikan pengaturan secara khusus terhadap penegak hukum yang dapat melakukan penyidikan. Penjelasan Pasal 25 UU Pornografi menegaskan bahwa penyidik adalah Pejabat Kepolisian Negara Republik Indonesia. Artinya, UU Pornografi membatasi penyidik sebatas pada Pejabat Kepolisian Negara Republik Indonesia. Perkembangan yang terjadi pada akhir tahun 2013, Presiden Susilo Bambang Yudhoyono berinisiatif membentuk Gugus Tugas Pencegahan dan Penanganan Pornografi melalui Peraturan Presiden Nomor 25 Tahun 2012 per 2 Maret 2012.13 Sebagai gugus Tugas yang diemban dan anggota yang terdiri dari Menteri dan Jaksa Agung, Ketua Komisi Penyiaran Indonesia (KPI), dan Ketua Lembaga Sensor Film (LSF). Keberadaan tim ini sama sekali tidak dikenal baik

\footnotetext{
${ }^{13}$ Laurencius Simanjuntak, "Presiden bentuk Satgas Anti-Pornografi", http://www.merdeka.com/politik/presiden-bentuk-satgas-anti-pornografi.html, 13 Maret 2012, diunduh 22 Januari 2016
} 
dalam KUHAP maupun UU Pornografi sehingga baik keberadaan tim maupun produk yang dihasilkan tidak dapat dimasukkan sebagai bagian dari penegakan hukum.

Berdasarkan penelusuran data putusan Mahkamah Agung Republik Indonesia terhadap perkara pidana pornografi terdapat 173 putusan yang telah mendapatkan kekuatan hukum tetap (inkracht van gewijsde). ${ }^{14}$ Sedangkan untuk perkara pidana pornografi melalui internet dapat tampak dalam dakwaan bahwa jaksa Penuntut Umum telah menggunakan bentuk dakwaan alternatif. Sebuah kasus Tindakan mempertontonkan video yang menampilkan seseorang dalam kondisi telanjang dan persenggamaan di kedai kopi dan menyimpan fail pornografi di sebuah flashdisk dalam berkas Putusan Nomor: 513/PID/2013/PTMDN dituntut dengan dakwaan alternatif, pertama melanggar Pasal 29 UU Pornografi dan Kedua melanggar Pasal 32 UU Pornografi. Dalam tahap pemeriksaan di sidang pengadilan dan putusan hakim, perkara pornogafi melalui internet yang sesuai dengan pasal 23 UU Pornografi tersebut menggunakan mekanisme yang diatur dalam KUHAP. Hal tersebut dapat dipahami mengingat UU Pornografi tidak memberikan pengaturan khusus mengenai tahap pemeriksaan di sidang pengadilan maupun putusan hakim.

Hal yang menarik dari pengaturan pasal 25 sampai dengan Pasal 27 UU Pornografi ditemukan sebuah istilah "data elektronik" yang tidak mendapatkan penjelasan lebih lanjut. Bila pemahaman terhadap "data elektronik" dihubungkan dengan pengaturan pasal 24 UU Pornografi, maka data yang dimaksudkan adalah semua informasi dalam bentuk elektonik. Data tersebut tidak hanya termasuk dalam ruang lingkup ITE akan tetapi termasuk di dalamnya informasi yang disampaikan melalui jaringan internet dan saluran komunikasi. Sebaliknya, UU ITE sama sekali tidak menyebutkan data elektronik sebagai istilah yang digunakan. Walaupun demikian pengakuan data elektronik sebagai alat bukti yang sah dalam perkara pornografi membuat kedudukan data elektronik tidak lagi ditolak sebagai barang bukti. Chazawi menegaskan bahwa sebelum pasal 24 UU

\footnotetext{
${ }^{14} \mathrm{http} / /$ putusan.mahkamahagung.go.id/main/pencarian/?q=pornografi+44+2008, diunduh 22 Januari 2016
} 
Pornografi berlaku, data elektronik diakui sebagai barang bukti yang memiliki fungsi tambahan (accesoir) atau sebagai alat bukti petunjuk. ${ }^{15}$ Pemberlakuan Pasal 24 UU Pornografi menjadikan data elektronik sebagai alat bukti yang sah dalam hukum acara pidana.

\section{Model Gabungan Hukum Pidana Formil pada Perkara Pidana Pornografi melalui Internet}

Secara yuridis formal memang UU ITE dan UU Pornografi telah memberikan pengaturan secara khusus terkait dengan hukum pidana formil. Hanya saja kedua undang-undang tersebut masih merujuk KUHAP sebagai ketentuan hukum pidana formil dasar yang akan diberlakukan sepanjang undangundang a quo memberlakukan lain (Pasal 42 UU ITE dan Pasal 23 UU Pornografi). Hukum Acara Pidana yang berlaku pun dimulai dari sejak tahap awal penyidikan sampai pada putusan pengadilan atas perkara pidana pornografi melalui internet.

Sejauh ini pengaturan khusus mengenai hukum pidana formil baik dalam UU ITE maupun UU Pornografi tidak bersifat mengurangi mekanisme hukum acara pidana yang diatur dalam KUHAP. Justru pengaturan khusus tersebut bersifat menambahkan mekanisme baru dalam penanganan perkara pidana pornografi melalui internet. Misalnya saja, pengaturan penyidikan pada perkara pidana ITE bagi penyidik diwajibkan mendasarkan penyidikan pada privasi, kerahasiaan, kelancaran layanan publik, integritas data, dan keutuhan data yang selama ini belum dikenal dalam KUHAP (pasal 43 ayat (2) UU ITE). Begitu pula dalam UU Pornografi diatur pemahaman baru tentang data elektronik sebagai alat bukti yang harus dilampirkan dalam berkas perkara (pasal 27 ayat (1) UU Pornografi). Berdasarkan pemahaman terhadap pengaturan khusus dalam hukum acara pidana yang diatur dalam UU ITE dan UU Pornogarfi maka pengaturan hukum acara pidana atas perkara pidana pornografi melalui internet bersifat saling melengkapi dan mendukung pelaksanaan hukum acara pidana dalam KUHAP.

${ }^{15}$ Adami Chazawi, Tindak Pidana: Pornografi, Putra Media Nusantara, Surabaya, 2009, hlm., 249. 
Penggunaan kedua ketentuan hukum tersebut dalam menangani perkara pidana secara khusus mengenai perkara pidana pornografi melalui internet dapat dilakukan mengingat karakteristik perbuatan pornografi melalui internet sendiri. Perbuatan pornografi melalui internet terkait erat dengan penggunaan sarana internet yang disalahgunakan untuk melakukan perbuatan yang dilarang yaitu menampilkan informasi yang memiliki muatan melanggar kesusilaan (Pasal 27 ayat (1) UU ITE) dan penampilan obyek pornografi yang menjadi obyek dilarang dalam UU Pornografi. Tentu saja pengaturan khusus dari kedua ketentuan hukum tersebut tetap didasarkan pada pengaturan hukum acara pidana sebagaimana berlaku dalam KUHAP. Pemberlakuan hukum acara pidana dalam KUHAP sama artinya dengan memberlakukan "criminal justice process" yang bersumber pada "criminal justice system". Atmasasmita16 menegaskan bahwa pengaturan KUHAP memberikan wewenang pada tiap aparat penegak hukum untuk bekerjasama sebagai sebuah sistem sehingga penanganan perkara akan mengikuti sebuah proses hukum yang jelas. Tahapan tersebut dimulai dari tahap penyelidikan, penyidikan, penuntutan, sampai pemeriksaan di muka sidang. Berikut disajikan tabel kombinasi hukum acara pidana yang berlaku dalam perkara pidana pornografi melalui internet dari tiap tahap penegakan hukum.

Tabel 3.

Model Gabungan Hukum Acara Pidana Khusus dalam Penanganan Perkara Pidana Pornografi melalui Internet

\begin{tabular}{|c|c|c|c|}
\hline TAHAPAN & KUHAP & UU ITE & UU PORNOGRAFI \\
\hline Penyelidikan & $\begin{array}{l}\text { Pasal } 5 \text { KUHAP } \\
\text { 1. Menerima laporan atau } \\
\text { pengaduan } \\
\text { 2. Mencari keterangan dan } \\
\text { barang bukti } \\
\text { 3. Menyuruh berhenti orang } \\
\text { yang dicurigai } \\
\text { 4. Tindakan lain menurut } \\
\text { hukum }\end{array}$ & $\begin{array}{c}\text { Tidak ada } \\
\text { pengaturan }\end{array}$ & \\
\hline Penyidikan & $\begin{array}{l}\text { 1. Tindakan dalam penyidikan } \\
\text { didasarkan pada wewenang } \\
\text { penyidik yaitu: } \\
\text { a. Penerimaan laporan atau } \\
\text { pengaduan tentang }\end{array}$ & $\begin{array}{l}\text { - Menerima laporan } \\
\text { atau pengaduan } \\
\text { dan pemeriksaan } \\
\text { dari seseorang } \\
\text { (pasal } 43 \text { angka } 5\end{array}$ & $\begin{array}{l}\text { - Wewenang } \\
\text { Penyidik untuk } \\
\text { membuka akses, } \\
\text { memeriksa, dan } \\
\text { membuat }\end{array}$ \\
\hline
\end{tabular}

16 Romli Atmasasmita, Bunga Rampai Hukum Acara Pidana, BinaCipta, Bandung, 1983, hlm., 16-17. 


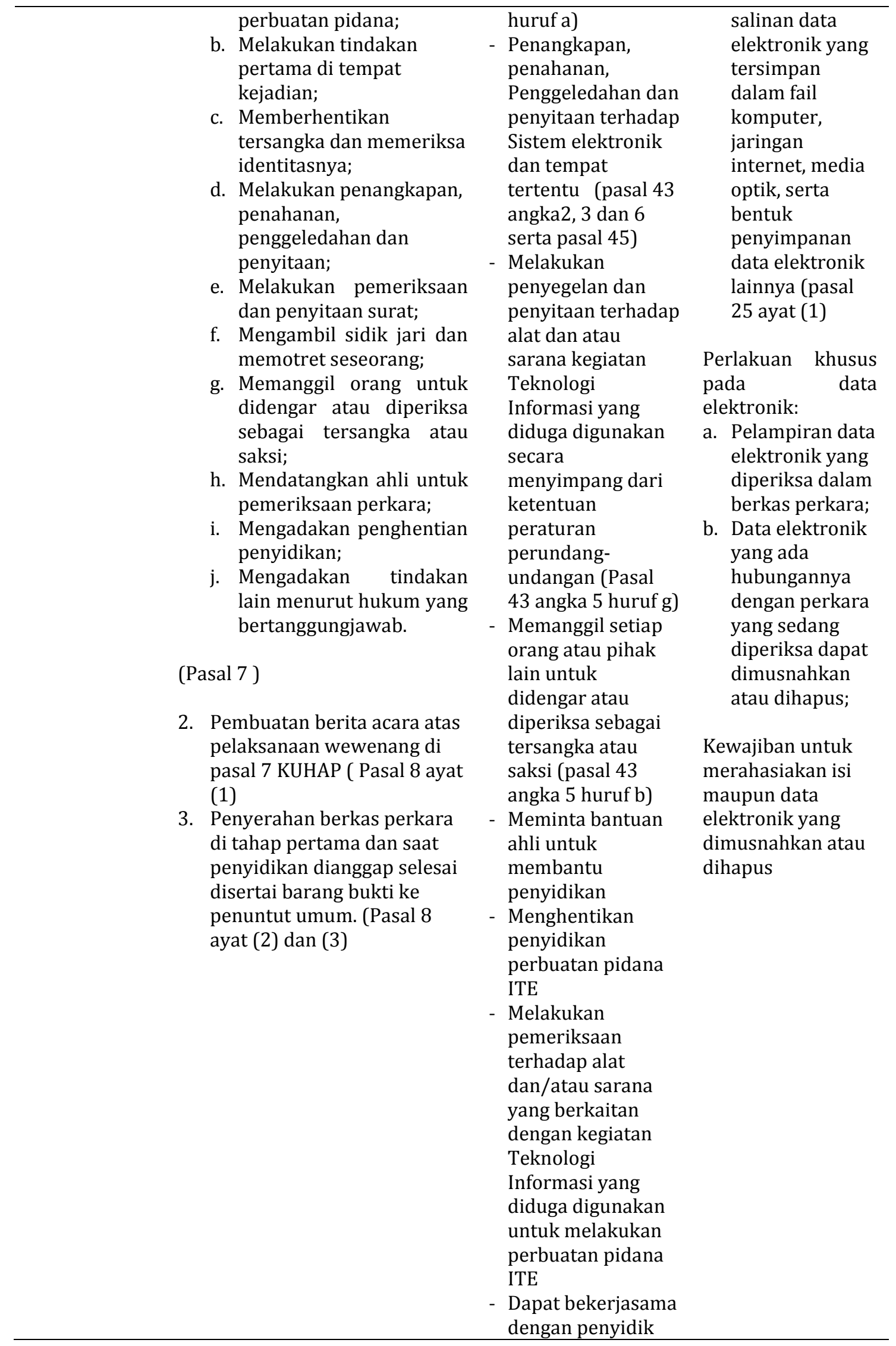


Negara lain untuk berbagi informasi

dan alat bukti

untuk mengungkap

perbuatan pidana

ITE

\begin{tabular}{|c|c|}
\hline Penuntutan & $\begin{array}{l}\text { 1. Penuntut Umum akan } \\
\text { melakukan wewenangnya } \\
\text { antara lain (pasal 14): } \\
\text { a. } \text { Menerima dan memeriksa } \\
\text { berkas perkara penyidikan } \\
\text { (pasal 138); } \\
\text { b. } \text { Mengadakan pra } \\
\text { penuntutan bila ada } \\
\text { kekurangan pada } \\
\text { penyidikan; } \\
\text { c. Memberikan perpanjangan } \\
\text { penahanan, melakukan } \\
\text { penahanan atau } \\
\text { penahanan lanjutan; } \\
\text { d. } \text { Membuat surat dakwaan } \\
\text { (Pasal 140 dan 143); } \\
\text { e. } \text { Melimpahkan perkara ke } \\
\text { pengadilan (pasal 143 ayat } \\
\text { (1); } \\
\text { f. } \text { Menyampaikan } \\
\text { pemberitahuan kepada } \\
\text { terdakwa tentang hari dan } \\
\text { waktu perkara di } \\
\text { sidangkan; } \\
\text { g. Melakukan penuntutan; } \\
\text { h. Menutup perkara demi } \\
\text { kepentingan hukum; } \\
\text { i. Mengadakan tindakan lain } \\
\text { dalam lingkup tugas dan } \\
\text { tanggung jawab penuntut } \\
\text { umum; } \\
\text { j. Melaksanakan penetapan } \\
\text { hakim. }\end{array}$ \\
\hline $\begin{array}{l}\text { Pemeriksaan } \\
\text { di Sidang } \\
\text { Pengadilan } \\
\text { (Acara } \\
\text { Pemeriksan } \\
\text { Biasa) }\end{array}$ & $\begin{array}{l}\text { 1. Pengadilan Negeri menerima } \\
\text { surat pelimpahan perkara } \\
\text { dari penuntut umum dan } \\
\text { mempelajarinya terkait } \\
\text { wewenang mengadili } \\
\text { perkara yang diajukan (pasal } \\
147 \text { dan 148); } \\
\text { 2. Pengadilan negeri menerima } \\
\text { dan mengadili perkara } \\
\text { tersebut (pasal 152 ayat (1); } \\
\text { 3. Pemanggilan terdakwa } \\
\text { untuk hadir persidangan } \\
\text { (pasal 145 dan pasal 152 } \\
\text { ayat (2) } \\
\text { 4. Permulaan sidang: -hakim: } \\
\text { pemeriksaan identitas }\end{array}$ \\
\hline
\end{tabular}




\begin{tabular}{|c|c|c|c|c|}
\hline & $\begin{array}{l}5 . \\
5 . \\
6 . \\
7 . \\
8 .\end{array}$ & $\begin{array}{l}\text { terdakwa - Penuntut umum: } \\
\text { membacakan surat dakwaan } \\
\text { Pemeriksaan sidang: } \\
\text { - Pemeriksaan saksi (pasal } \\
\text { 159) } \\
\text { - Bantuan keterangan saksi } \\
\text { ahli (pasal } 179 \text { dan 180); } \\
\text { - Pemeriksaan barang bukti } \\
\text { (pasal 181) } \\
\text { Pengajuan Tuntutan pidana } \\
\text { oleh Penuntut Umum (pasal } \\
\text { 182 ayat (1); } \\
\text { Pengajuan pembelaan oleh } \\
\text { pihak terdakwa dan jawaban } \\
\text { oleh penuntut umum (pasal } \\
\text { 182 ayat (2) dan (3) } \\
\text { Musyawarah oleh majelis } \\
\text { hakim berdasarkan surat } \\
\text { dakwaan (pasal 182 ayat (3)- } \\
\text { (8) }\end{array}$ & & \\
\hline $\begin{array}{l}\text { Putusan } \\
\text { Hakim }\end{array}$ & $\begin{array}{l}1 . \\
2 . \\
3 .\end{array}$ & $\begin{array}{l}\text { Hakim menjatuhkan putusan } \\
\text { berdasarkan minimal } 2 \text { alat } \\
\text { bukti yang sah dan } \\
\text { keyakinan hakim (pasal } \\
\text { 183); } \\
\text { Alat bukti yang sah yaitu } \\
\text { keterangan saksi, keterangan } \\
\text { ahli, surat, petunjuk dan } \\
\text { keterangan terdakwa (pasal } \\
\text { 184) } \\
\text { Pengadilan menjatuhkan } \\
\text { pidana apabila menilai } \\
\text { terdakwa bersalah (pasal } \\
\text { 193 ayat (1) yang diucapkan } \\
\text { di sidang terbuka untuk } \\
\text { umum (pasal 195) } \\
\text { Putusan harus dicantumkan } \\
\text { dalam surat putusan (pasal } \\
\text { 199) dan ditandatangani } \\
\text { hakim dan panitera setelah } \\
\text { putusan diucapkan (pasal } \\
\text { 200) } \\
\text { Panitera membuat berita } \\
\text { acara sidang (pasal 202) }\end{array}$ & $\begin{array}{l}\text { Informasi elektronik } \\
\text { dan/atau Dokumen } \\
\text { elektronik sebagai } \\
\text { alat bukti (pasal } 44 \\
\text { huruf b) }\end{array}$ & $\begin{array}{l}\text { Pengakuan data } \\
\text { dalam bentuk } \\
\text { tulisan atau } \\
\text { gambar dalam } \\
\text { bentuk cetakan, } \\
\text { elektronik, optic } \\
\text { atau bentuk } \\
\text { penyimpanan } \\
\text { sebagai alat bukti } \\
\text { (pasal } 24 \text { huruf a \& } \\
\text { b) }\end{array}$ \\
\hline
\end{tabular}

Berdasarkan Tabel 3. tersebut tampak bahwa pengaturan khusus hanya memberikan tambahan terhadap mekanisme baru dalam proses penyidikan dan alat bukti baru dalam perkara pidana pornografi melalui internet. Secara keseluruhan dapat diartikan bahwa hukum acara pidana sebagaimana diatur 
dalam KUHAP masih tetap menjadi pedoman utama. Walaupun UU ITE dan UU Pornografi tidak memberikan pengaturan terhadap penyelidikan, tahap ini tetap berlaku sebagai bagian dari proses hukum acara pidana yang berlaku sesuai KUHAP. Dengan tidak diaturnya pelaksana penyelidikan dalam UU ITE maupun UU Pornografi maka penyelidik yang dimaksud adalah Pejabat Kepolisian Negara Republik Indonesia. Penyelidikan menjadi "monopoli tunggal” polisi17 yang tidak boleh dilakukan campur tangan terhadapnya.

Keunggulan dari pengaturan khusus yang ada dalam UU ITE maupun UU Pornografi lebih terdapat pada penekanan peran serta masyarakat dalam proses penyidikan pornografi melalui internet dengan cara melakukan pengaduan atau laporan kepada penyidik. Pengaturan akan pengaduan dan laporan dari masyarakat ini menunjukkan adanya peran penting masyarakat sebagai pihak yang aktif dalam melakukan pencegahan sekaligus penanggulangan pornografi melalui internet. Pengaturan penyidikan terhadap sarana-sarana atau alat telekomunikasi beserta pemeriksaan terhadap data yang tersimpan dalam fail komputer, jaringan internet, media optik, serta bentuk penyimpanan data elektronik lainnya memudahkan penyidik untuk melakukan penanganan pornografi melalui internet. Sebagaimana diketahui KUHAP tidak memberikan pengaturan terhadap pemeriksaan terhadap sarana, fail komputer, jaringan internet, media optik, maupun penyimpanan elektronik sehingga dalam praktek penyidikan menimbulkan kendala bagi penyidik.

Ketentuan hukum pasal 184 KUHAP hanya mengenal 5 (lima) alat bukti yang sah sedangkan alat bukti berupa dokumen elektronik dan/atau informasi elektronik memiliki ciri yang berbeda dengan alat bukti yang sudah diatur. Hal tersebut merupakan salah satu ciri perkembangan hukum pembuktian modern yang selalu menyesuaikan diri dengan perkembangan teknologi dan ilmu pengetahuan. ${ }^{18}$ Pengakuan dokumen elektronik dan/atau informasi elektronik semakin mempermudah penyidik untuk melakukan pengumpulan barang bukti

\footnotetext{
17 M. Yahya Harahap, Pembahasan, Permasalahan dan Penerapan KUHAP: Penyidikan dan Penuntutan, Sinar Grafika, Jakarta, 2010.

18 Eddy O.S. Hiariej, Teori dan Hukum Pembuktian, Erlangga, Jakarta, 2012, hlm., 13.
} 
dari perkara pornografi melalui internet sehingga penyebarluasan pornografi dapat ditanggulangi dengan cepat. Lebih lanjut Hiariej menegaskan bahwa adanya rekaman video atau data elektronik merupakan physical evidence atau real evidence. ${ }^{19}$ Data elektronik yang ada sudah menjadi bukti yang cukup untuk menerangkan perbuatan pidana yang terjadi selanjutnya hanya diperlukan keterangan pakar telematika dan ahli reka wajah untuk membuktikan keaslian pelaku dalam data elektronik. ${ }^{20}$ Selanjutnya pembuktian dilakukan sesuai dengan Pasal 183 KUHAP yang menerapkan teori pembuktian berdasarkan UndangUndang secara Negatif (Negatief Wettelijk). Alat bukti yang ada di dalam pasal 184 KUHAP harus dibuktikan dalam persidangan sehingga berdasarkan alat bukti yang sah tersebut hakim dapat memperoleh keyakinan ${ }^{21}$ untuk memutus perkara.

Gabungan hukum acara pidana yang berlaku dalam UU ITE dan UU Pornografi dengan mendasarkan pemberlakuannya pada KUHAP menjadi hal yang sangat menguntungkan. Hal tersebut didasarkan pada pemahaman bahwa KUHAP telah memberikan pengaturan secara jelas terhadap mekanisme dan prosedur beracara dalam proses penegakan hukum pidana dari penyelidikan sampai putusan hakim. UU ITE dan UU Pornografi secara yuridis normatif ternyata memberikan pengaturan yang menambahkan wewenang, mekanisme dan alat bukti baru sebagai bentuk perkembangan hukum acara pidana. Penggabungan hukum acara pidana tersebut merupakan bagian dari upaya harmonisasi peraturan hukum yang sangat menunjang pembangunan hukum nasional pada masalah penegakan hukum. ${ }^{22}$ Gabungan hukum acara pidana disini ditekankan pada upaya penanggulangan perbuatan pornografi melalui internet dalam proses hukum acara pidana yang sudah diatur dengan jelas pada ketentuan hukum pidana yang berlaku. Hanya saja sampai sejauh ini baik UU ITE maupun UU Pornografi memiliki penekanan tersendiri yang memungkinkan untuk

\footnotetext{
19 Id. 14

20 Eddy O.S. Hiariej, “Pyhsical Evidence \& Pornografi”, Seputar Indonesia, 9 Juli 2010, hlm., 12.

${ }^{21}$ Andi Hamzah, Hukum Acara Pidana Indonesia, Sinar Grafika, Jakarta, 2004, hlm., 250.

22 Wicipto Setiadi, "Pembangunan Hukum Dalam Rangka Peningkatan Supremasi Hukum", Jurnal Rechtsvinding, Vol. 1, No. 1, Januari-April 2012, Jakarta, hlm., 12
} 
digabungkan secara bersama-sama sebagai bentuk hukum acara pidana khusus terkait perkara pornografi melalui internet.

\section{Penutup}

Pengaturan mekanisme penegakan hukum atas perkara pornografi melalui internet telah mendapatkan pengaturan secara khusus dalam UU ITE dan UU Pornografi. Pengaturan khusus terhadap hukum pidana formil dalam perkara pidana pornografi melalui internet telah dilakukan secara parsial dalam UU ITE dan UU Pornografi yang berfokus pada tahap penyidikan. UU ITE menitik beratkan pada tahap penyidikan dengan memberikan pengaturan baru terhadap PPNS dalam Kementerian Komunikasi dan Informatika sebagai penyidik, wewenang dan mekanisme penyidikan terhadap sarana dan/atau sistem elektronik serta alat bukti baru berupa dokumen elektronik dan/atau informasi elektronik. Sedangkan UU Pornografi memberikan penambahan wewenang penyidik untuk melakukan pemeriksaan pada data atau file yang disimpan dalam segala bentuk media penyimpanan ditambah dengan pengakuan data elektronik sebagai alat bukti yang diakui. Hanya saja pengaturan dari kedua Undang-Undang tersebut dapat diintegrasikan atau dipadukan dengan mekanisme penegakan hukum sebagaimana diatur dalam KUHAP justru menjawab kebutuhan mekanisme dan alat bukti baru dalam menangani perkara pidana pornografi melalui internet. Penegak hukum pun harus memperhatikan pengaturan hukum pidana formil dalam KUHAP, UU ITE maupun UU Pornografi mengingat ketiganya memiliki kombinasi yang mendukung penanganan perkara pornografi melalui internet secara lebih efisien.

\section{Daftar Pustaka}

\section{Buku}

Adami Chazawi, Tindak Pidana Pornografi, Putra Media Nusantara, Surabaya, 2009.

Andi Hamzah, Hukum Acara Pidana Indonesia, Sinar Grafika, Jakarta, 2004. Asas-Asas Hukum Pidana, Rineka Cipta, Jakarta, 2010. 
Dewi Bunga, Prostitusi Cyber: Diskursus Penegakan Hukum dalam Anatomi Kejahatan Transnasional, Udayana University Press, Bali, 2012.

Eddy O.S. Hiariej, Teori dan Hukum Pembuktian, Erlangga, Jakarta, 2012.

E.Y. Kante, \& Sianturi, S.R., Asas-asas Hukum Pidana di Indonesia dan Penerapannya, Storia Grafika, Jakarta, 2012.

M. Yahya Harahap, Pembahasan, Permasalahan dan Penerapan KUHAP: Penyidikan dan Penuntutan, Sinar Grafika, Jakarta, 2010.

Nikolas Simanjuntak, Acara Pidana Indonesia dalam Sirkus Hukum, Ghalia Indonesia, Bogor, 2009.

Romli Atmasasmita, Bunga Rampai Hukum Acara Pidana, BinaCipta, Bandung, 1983.

Soemarno Partodihardjo, Tanya Jawab Sekitar Undang-Undang Nomor 11 Tahun 2008 tentang Informasi dan Transaksi Elektronik, Gramedia Pustaka Utama, Jakarta, 2009.

\section{Jurnal}

Wicipto Setiadi, "Pembangunan Hukum Dalam Rangka Peningkatan Supremasi Hukum", Jurnal Rechtsvinding, Vol. 1, No. 1, Januari-April 2012, Jakarta

\section{Lain-Lain}

Hiariej, Eddy O.S., "Pyhsical Evidence\& Pornografi”, Seputar Indonesia, 9 Juli 2010 Siaran Pers No. 101/PIH/KOMINFO/12/2015, "Siaran Pers tentang Pemblokiran Situs Judi dan Pornografi", http://kominfo.go.id/index.php/content/detail/6555/Siaran-Pers-NO101-PIH-KOMINFO-12-2015-Tentang-Pemblokiran-Situs-Judi-danPornografi-/0/siaran_pers\#.Vqb6QVJjLIU, 31 Desember 2015, dunduh 22 Januari 2016.

Mahkamah konstitusi, http://putusan.mahkamahagung.go.id/, putusan diunduh 22 Januari 2016.

Laurencius Simanjuntak, "Presiden bentuk Satgas Anti-Pornografi", http://www.merdeka.com/politik/presiden-bentuk-satgas-antipornografi.html, 13 Maret 2012, diunduh 22 Januari 2016 